\title{
Intestinal adenocarcinoma in a European brown bear (Ursus arctos) - a case report
}

\author{
Marko Hohšteter ${ }^{1}$, Ivan-Conrado Šoštarić-Zuckermann ${ }^{1 *}$, Slaven Reljić ${ }^{2}$, \\ Lidija Medven Zagradišnik ${ }^{1}$, Branka Artuković1, Željko Grabarević1, \\ Josip Kusak ${ }^{2}$, Đuro Huber ${ }^{2}$, and Andrea Gudan Kurilj ${ }^{1}$ \\ ${ }^{\prime}$ Department of Veterinary Pathology, Faculty of Veterinary Medicine, University of Zagreb, Zagreb, Croatia \\ ${ }^{2}$ Department of Biology, Faculty of Veterinary Medicine, University of Zagreb, Zagreb, Croatia
}

HOHŠTETER, M., I.-C. ŠOŠTARIĆ-ZUCKERMANN, S. RELJIĆ, L. MEDVEN ZAGRADIŠNIK, B. ARTUKOVIĆ, Ž. GRABAREVIĆ, J. KUSAK, Đ. HUBER, A. GUDAN KURILJ: Intestinal adenocarcinoma in a European brown bear (Ursus arctos) - a case report. Vet. arhiv 88, 569-579, 2018.

\section{ABSTRACT}

This article presents the first case of intestinal adenocarcinoma in a free living, culled 12 year old, European female brown bear (Ursus arctos), with its characteristic macropathological and histopathological manifestations. Necropsy revealed thoracic gunshot injuries (compassionate shot) and the poor physical condition of the animal, with body fat loss and musculature atrophy. An infiltrative mass protruded the jejunal wall with infiltration of the mesentery, visceral and parietal peritoneum, and distal parts of the colon and rectum. The histopathological examination presented an infiltrative, unencapsulated, moderately cellular neoplastic mass, composed of an epithelial cell population, forming irregular nests, papillary and ribbon like structures and small number of tubules, surrounded by an extensive desmoplastic reaction. Within the tumor a small number of cysts filled with mucin were noted. The epithelial neoplastic cells exhibited mild anisocytosis and anisokaryosis, and a low mitotic index. Histochemical Van Gieson staining showed strong positivity in the desmoplastic proliferation. The epithelial tumor cells were positively imunostained with cytokerain, and stromal cells with vimentin. The histological features presented are characteristic of intestinal adenocarcinomas, of the mixed tubular and mucinous type, with a prominent scirrous reaction.

Key words: intestinal adenocarcinoma; European brown bear (Ursus arctos); macropathology; histopathology; immunohistochemistry

\footnotetext{
*Corresponding author:

Assist. Prof., Ivan-Conrado Šoštarić-Zuckermann, PhD, DVM, Department of Veterinary Pathology, Faculty of Veterinary Medicine, University of Zagreb, Heinzelova 55, 10000 Zagreb, Croatia, Phone: +385 12390 314; Fax: +385 12441 390; E-mail: ivan_conrado@yahoo.com
} 


\section{Introduction}

Intestinal tumors are, with the exception of cats, rare tumors in domestic animals and are generally malignant in all animal species, with rare cases of benign tumors. In cats, intestinal neoplasms are frequently reported, and represent $5 \%$ to $9.3 \%$ of all tumors, with a predominance of lymphoma (60\%), followed by adenocarcinoma $(28 \%)$ and mastocytoma (5.3\%). Canine intestinal tumors have a prevalence from $0.6 \%$ to $0.7 \%$ and the most common tumors are adenocarcinomas $(65 \%)$ and lymphomas $(25 \%)$ (WILLARD, 2012; MUNDAY et al., 2017). Gastrointestinal neoplasms are rare in other animal species, and they mainly involve the small intestine. Lymphosarcoma, intestinal adenocarcinoma and gastrointestinal stromal tumors, similar to dogs and cats, are the most commonly diagnosed neoplasms in other domestic animals (UZAL et al., 2016).

The etiology of intestinal adenocarcinoma in deer is related to bracken fern intoxication. This intoxication causes tumors in cattle if a simultaneous infection with bovine papillomavirus is present. In sheep, herbicides are a suspected cause of intestinal adenocarcinoma. Genetic disorders are supposed to influence the development of intestinal cancers in humans, and some breeds of dogs, cats and sheep (KELLY et al., 2014).

There have been relatively few reports of tumors in bears (Ursus sp.). The most prevalent tumors are hepatic neoplasms (hepatocellular and biliary carcinoma) (VASHIST et al., 2013) and bone tumors, such as osteosarcoma, chondrosarcoma and osteoma (MURAKAMI et al., 2012), followed by lymphoma (BECK et al., 2016), mammary gland tumors and squamous cell carcinoma (VASHIST et al., 2013). Other types of neoplasms, such as thyroid cystadenoma, meduloblastoma, teratoma, ovarian carcinoma and meningioma, have been reported individually (STORMS et al., 2004; CHIEN et al., 2013; MUNK et al., 2013; MITCHELL et al., 2015; ROSSI et al., 2016).

There are no documented cases of primary gastrointestinal epithelial tumors in bear species. In this article we present the first case of intestinal adenocarcinoma in a free living European brown bear (Ursus arctos), with its characteristic macropathological and histopathological manifestations.

\section{Case history}

The carcass of a 12 year old female European brown bear (Ursus arctos) was delivered for pathological examination to the Department of Veterinary Pathology, Faculty of Veterinary Medicine, University of Zagreb. Her age was determined by Matson's Laboratory, Montana, USA (MATSON et al., 1993). The presented bear lived in the district of Ogulin, Croatia ( $\varphi$ 45.278, $\lambda$ 15.161), and was shot to death compassionately by a gamekeeper due to chronic illness and poor body condition.

Necropsy findings. Upon necropsy, the animal was in very poor physical condition, weighing $56.6 \mathrm{~kg}$, with extensively pronounced bone protrusions (Fig. 1). 


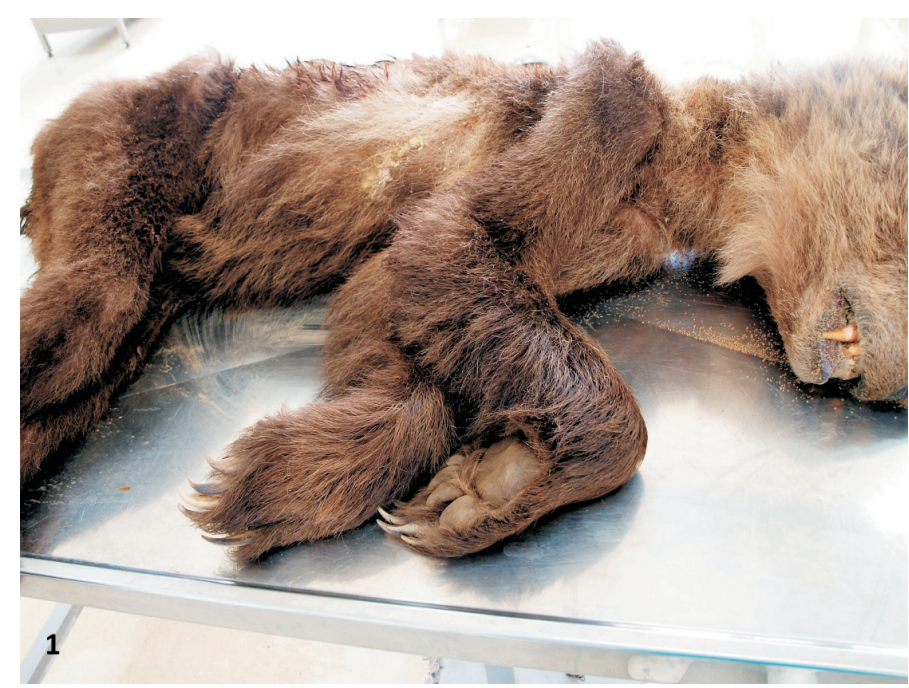

Fig. 1. European brown bear (Ursus arctos), animal in poor body condition with extensively pronounced bone protrusions

The gunshot wound, measuring $25 \mathrm{~mm}$ in diameter, was present on the right side of the thorax. The body fatty subcutaneous and intraabdominal tissue was severely depleted, and there was extensive atrophy of the skeletal muscles. The $5^{\text {th }}$ and $6^{\text {th }}$ righthand ribs were fractured and surrounded by massive hemorrhages in the adjacent muscles and subcutis. The pericardium and intrapericardial part of the aorta were ruptured, and consequently the pericardium and the thoracic cavity were filed with approximately $500 \mathrm{~mL}$ of partially coagulated blood, admixed with irregularly shaped bone and metal fragments. The pulmonary pleura were multifocally ruptured and there were extensive pulmonary hemorrhages. Examination of the abdominal cavity revealed an infiltrative mass measuring approximately $15 \mathrm{~cm}$ in diameter (Fig. 2). The mass protruded into the small intestine wall, and infiltrated and formed adhesions to the mesentery, visceral peritoneum, and distal parts of the colon and rectum. In the stomach, a small amount of brown mucinous content was present. The wall of the middle part of the jejunum was thickened and measured from $15 \mathrm{~mm}$ to $15 \mathrm{~cm}$ on the side of mesenteric attachment, thus markedly narrowing the lumen and forming the previously described abdominal mass. On the surface and cross section the mass was heterogeneous, hard, elastic and whitish to red brown in color. Multiple necrotic gray foci and irregular cavities filled with brown mucinous fluid were observed within the tumor (Fig. 3). The lumen of the jejunum proximally to the neoplasm was markedly distended, containing a moderate amount of reddish brown mucinous fluid, with 15-20 cestodic parasites, and the distal parts of 
M. Hohšteter et al.: Intestinal carcinoma in a European brown bear

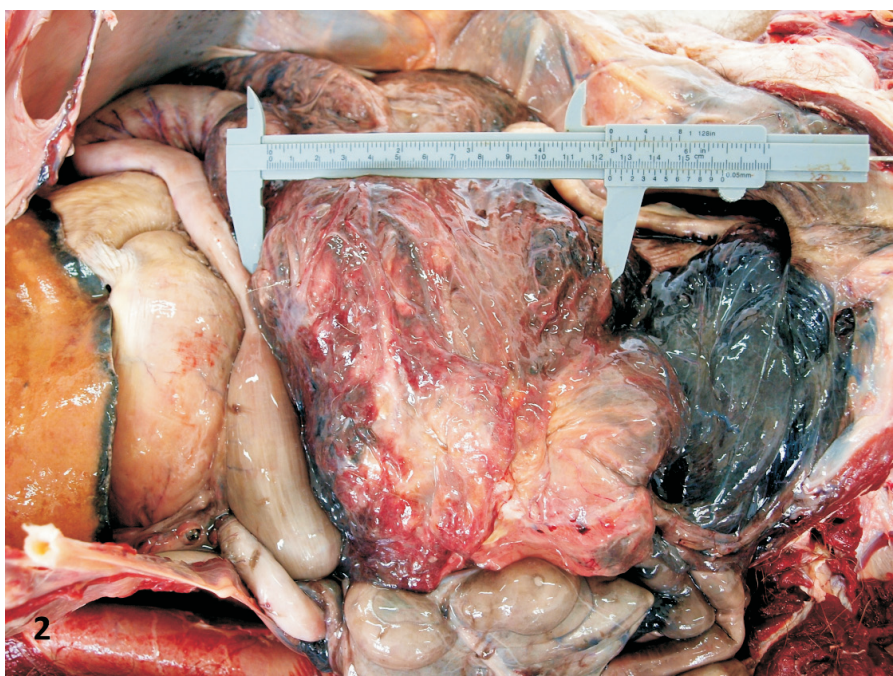

Fig. 2. European brown bear (Ursus arctos), abdominal cavity, infiltrative neoplastic mass (intestinal adenocarcinoma) protruding the jejunal wall with infiltration and adhesions to the mesentery, visceral peritoneum, distal parts of colon and rectum

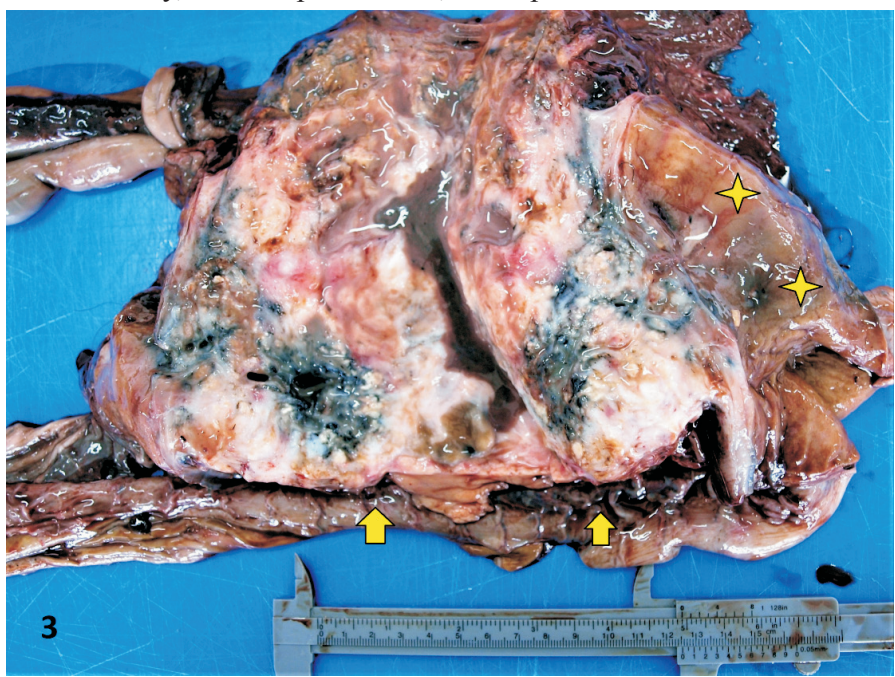

Fig. 3. European brown bear (Ursus arctos), intestinal adenocarcinoma, cut surface.

Heterogeneous mass, whitish to red brown in color. Multiple necrotic (gray) areas and irregular cysts filled with a mucinous (brown) fluid. Markedly narrowed jejunal lumen (arrows), distended lumen of the jejunum proximal to the tumor (asterisks). 
small and large intestines contained a small amount of the previously described content. Approximately $30 \mathrm{~cm}$ distal to the neoplasia, a focal, oval, plaque-like proliferation of the jejunal mucosa, around $15 \mathrm{~mm}$ in diameter and a $5 \mathrm{~mm}$ tick were observed. The remaining organs and tissues appeared macroscopically normal, with a moderate grade of autolysis.

Histopathological findings. Samples of the tumor and other organs were fixed in 10\% neutral buffered formalin, embedded in paraffin wax, and $5 \mu \mathrm{m}$ sections were stained with hematoxylin and eosin (H\&E) for routine histopathological examination. In addition, selected sections of the abdominal mass and jejunum were stained with Gramm and Van Gieson stains. Immunohistochemical analysis (IHC) of neoplastic mass sections was performed with anti-vimentin rabbit polyclonal antibody (DAKO) and anti-cytokeratin AE1/AE3 polyclonal antibody (DAKO).

Histopathological findings of the lungs, aorta and skeletal muscle showed multiple, focally extensive to coalescing hemorrhages. The histopathological examination of the jejunal mass showed an expansive, infiltrative, poorly demarcated,unencapsulated, moderately cellular neoplastic mass, which had infiltrated and destroyed all the layers of the jejunal wall (tunica mucosa, submucosa, muscularis and serosa). The neoplasm was composed of epithelial cells forming irregular nests, papillary and ribbon like structures, and a small number of tubules surrounded by an extensive desmoplastic reaction, characterized by wide interlacing bundles of fibrous reactive stroma (Fig. 4). The neoplastic epithelial cells were columnar, cuboidal to oval, and exhibited modest anisocytosis and anisokaryosis. Most of the cells presented distinct cell borders and a moderate amount of eosinophilic cytoplasm. The nuclei were round to oval, containing reticular to granular chromatin, and one or two irregular nucleoli. Mitoses were rare. Multifocally in the neoplastic nests, extensive single and massive cell necrosis were observed, with an accumulation of cellular debris in the lumen of some tubules. Within the tumor, a small number of acini and cysts were present, filled with pale blue mucin and lined by neoplastic epithelial cells (Fig. 5). The intestinal mucosa was multifocally ulcerated and, in the neoplastic proliferation and adjacent stroma, multifocal areas of necrosis, haemorrhages and inflammatory cell infiltrates were noted, with a predominance of macrophages and fewer neutrophils, lymphocytes and plasma cells. Foci of mineralization were evident in some necrotic centers. The same histopathological findings, with a mild desmoplastic scirrous reaction, were noted in the sample of the distal jejunal wall thickening. The described neoplastic proliferations were noted in multiple samples of the peritoneum. The presented histological features are characteristic for intestinal adenocarcinomas, of the mixed tubular and mucinous type, with a prominent scirrous reaction (MUNDAY et al., 2017; UZAL et al., 2016). 


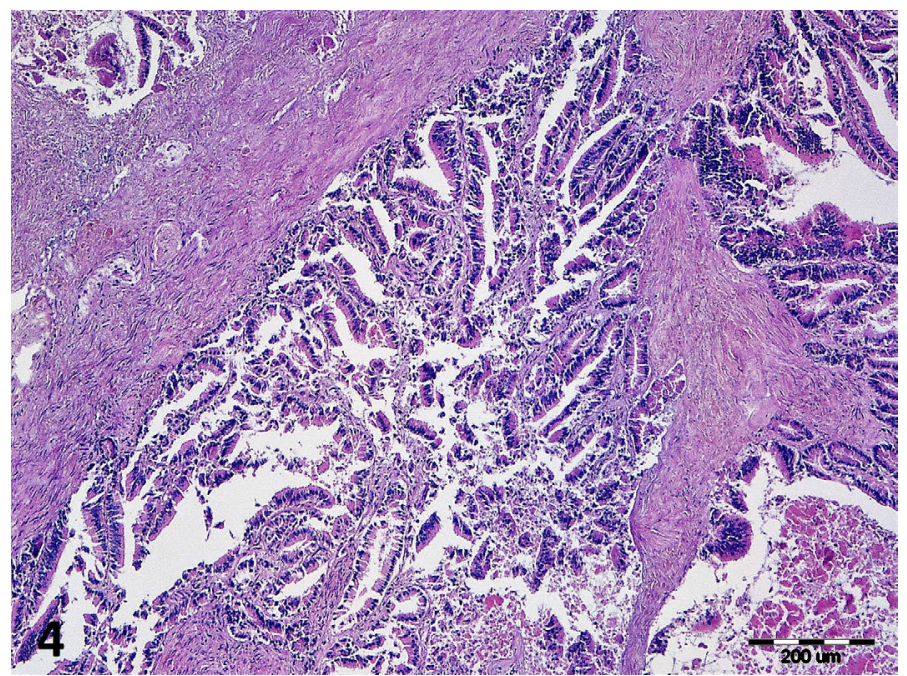

Fig. 4. European brown bear (Ursus arctos), jejunum, intestinal adenocarcinoma. Tubular and papillary neoplastic proliferations surrounded by extensive fibrous stroma. H\&E, $\times 200$.

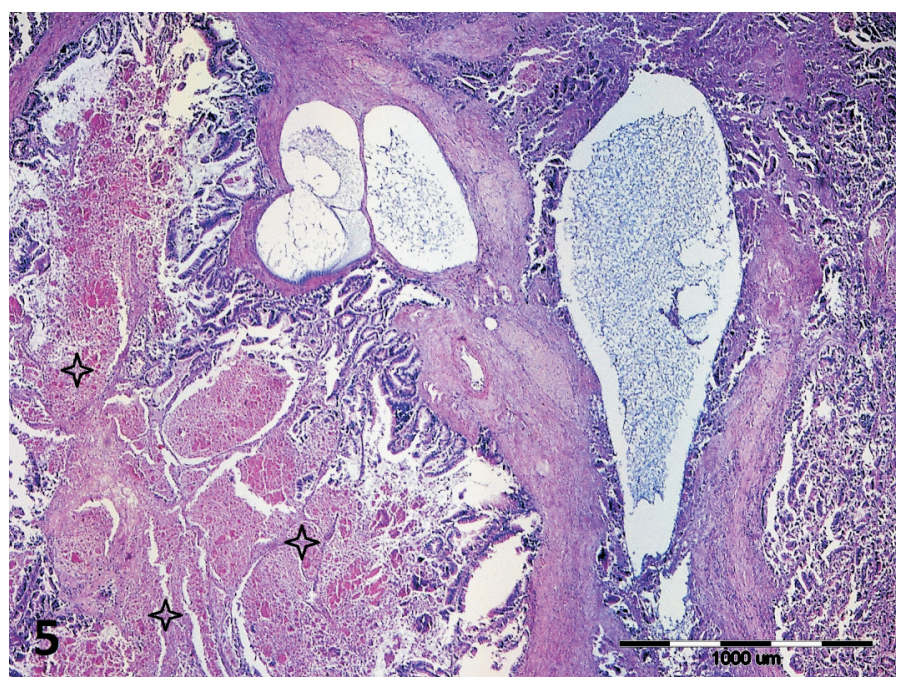

Fig. 5. European brown bear (Ursus arctos), jejunum, intestinal adenocarcinoma. Multiple cysts filed with pale blue mucin and areas of necrosis characterized by amorphous eosinophilic cellular debris (asterisks). H\&E, $\times 40$. 
Van Gieson staining differentiated a high amount of collagen fibers (red staining) in the adjacent tumor stroma, while Gramm staining showed blue staining of bacillary and coccoid bacteria (Gramm positive) in the inflamed and necrotic foci.

Immunohistochemical analysis showed the strong cytoplasmic positivity of the neoplastic epithelial cells for cytokeratin, and the stromal cells showed positive cytoplasmic vimentin staining (Fig. 6).

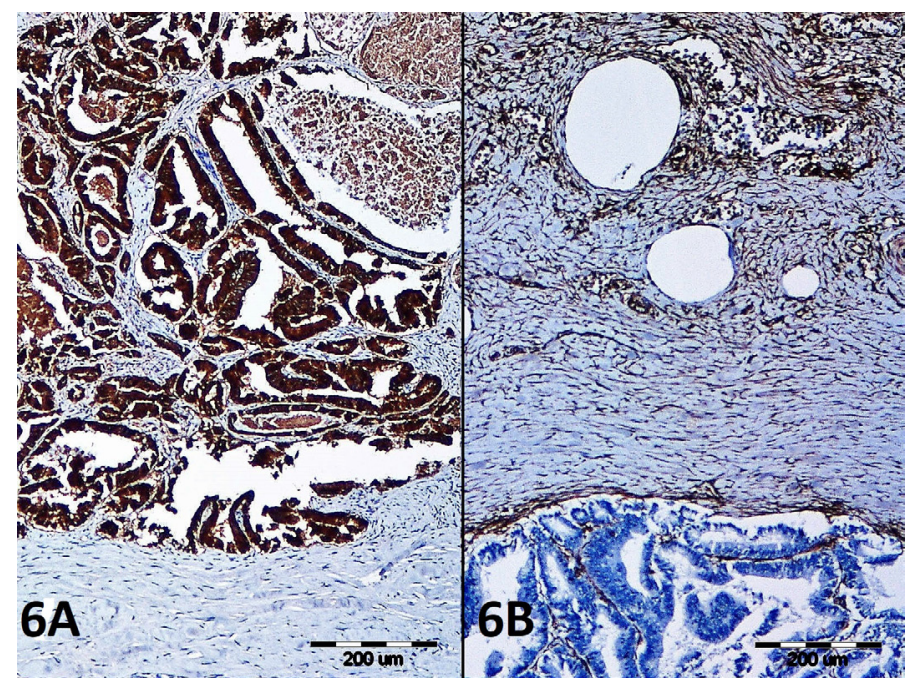

Fig. 6. European brown bear (Ursus arctos), jejunum, intestinal adenocarcinoma, immunohistochemistry. A) Strong cytoplasmic cytokeratin positivity of neoplastic epithelial cells (brown staining), negative reaction in stromal cells (blue staining). B) Positive cytoplasmic vimentin staining of stromal cells (brown staining), negative reaction in epithelial cells (blue staining), $\times 100$.

\section{Discussion}

The diagnosis of intestinal adenocarcinoma was based on the macroscopic and histopathological findings, which were identical to those described in the literature (WILLARD, 2012; MUNDAY et al., 2017; UZAL et al., 2016). The diagnosis was supported by Van Giesson differential histochemical staining, which showed the abundant proliferation of collagen rich, fibrous tissue within the tumor stroma, and by immunohistochemical analysis, with a positive cytokeratin reaction of the epithelial component, and vimentin expression in the stromal component of the tumor (SALAMANCA et al., 2008; MUNDAY et al., 2017). 
The macroscopic and histopathological examination revealed infiltrative tumor growth, with contact metastases to peritoneal surfaces. However, no distant metastases were noted. Distant metastases (predominantly peritoneal and hepatic) are reported in dogs in $67 \%$ of necropsied animals with small intestinal adenocarcinoma (PATNAIK et al., 1980). So far, thereare no data that suggest that the histological subtype of intestinal adenocarcinoma predicts the biological behavior of this type of tumor in domestic animals. In contrast to this, a histological type of tumor in humans is associated with biological behavior, e.g. medullary tumors in humans have better prognosis, and signet ring tumors of the small intestine, worse (WASHINGTON, 2008). At the same time, human intestinal carcinomas are, regarding prognosis, subdivided into either low malignancy grade if $>50 \%$ of the cells are in glands, or high grade if $<50 \%$ of the cells are in glands (COMPTON, 2003). Taking all of the above into account, this type of adenocarcinoma, with just a small ratio of glands formed in the tumor tissue, would be histologically considered as a high malignancy grade tumor in humans with very common distant metastasis. In the present case there were only contact metastases to the peritoneum and not to the distant organs (lungs, liver, spleen etc.). On this basis, we may presume that in our case, as in dogs, the criteria are not the same that relate the histopathological characteristics of this tumor with its biological behavior.

All the other pathological findings identified may be a consequence of tumor proliferation. It is well known that intestinal carcinomas can cause anorexia, vomiting, obstruction, diarrhea, weight loss and bleeding (WILLARD, 2012). In the present case the animal was severely emaciated, which in our opinion is related to two effects of the tumor The first is the direct involvement of the intestinal tract and constriction of the intestine due to a severe desmoplastic reaction and consequently the dysregulation of digestion. Multiple ulcerations of the neoplastically infiltrated mucosa caused intestinal bleeding and the resulting anaemia. The second is probably related to the paraneoplastic effect and secretion of tumor necrosis factor, interleukin 1 and 6, interferon $\alpha$ and $\gamma$, in conjunction with increased serum lactate and insulin levels. All these changes redirect the patient's metabolism into gluconeogenesis and protein catabolism, with the end result of musculature atrophy and cancer cachexia (CULLEN and BREEN, 2017).

The cancer itself and the concurrent cachexia are commonly reported in humans and in domestic animals, but are rarely reported in wild animals. The small number of tumors diagnosed in bears, similar to all free-living wild animals, can be at least partially explained as a result of the low incidence of inbreeding in contrast to domestic animals (CULLEN and BREEN, 2017; MADSEN et al., 2017). The low incidence of reports of tumors in wild animals is also based on the effect of natural selection whereby animals suffering from neoplastic diseases usually do not die primarily as a consequence of the tumor. Due to the malignant process animals develop infectious and parasitic diseases 
and suffer exhaustion thus becoming easier prey to their natural predators (MADSEN et al., 2017).

In conclusion, every new recorded case of tumors in wild animals can provide valuable data for studies in comparative oncology and the etiology of neoplastic diseases (MADSEN et al., 2017). The present case of an intestinal adenocarcinoma, described here with all the typical effects of the tumor on the animal, is to our knowledge the first report of this type of tumor in a European brown bear (Ursus arctos), as well as in other bear species.

\section{Acknowledgements}

This study was supported by two EU funded projects: LIFE DINALP BEAR, LIFE13 NAT/SI/000550 and FP7-ERA Chairs-PilotCall-2013 project, acronym: VetMedZg (Grant agreement No: 621394). The Biology Department was additionally supported by EURONATUR and BERND THIES foundations.

\section{References}

BECK, A., S. RELJIĆ, I.-C. ŠOŠTARIĆ-ZUCKERMANN, M. WRZOSEK, D. HUBER (2016): Primary bilateral renal diffuse large B-cell lymphoma with central nervous system metastases in a captive brown bear (Ursus arctos) - a case report. Vet. arhiv 86, 857-865.

CHIEN, Y. C., C. Y. LIEN, J. C. GUO, S. C. CHIN, Y. P. CHANG, C. H. LIU (2013): Meningothelial meningioma in a Malayan sun bear (Helarctos malayanus). J. Vet. Diagn. Invest. 25, 636-640. DOI: $10.1177 / 1040638713499342$

COMPTON, C. C. (2003) Colorectal carcinoma: diagnostic, prognostic, and molecular features. Mod. Pathol. 16, 376-388.

DOI: 10.1097/01.MP.0000062859.46942.93

CULLEN, J. M., M. BREEN (2017): An overview of molecular cancer pathogenesis, prognosis, and diagnosis. In: Tumors in Domestic Animals, $5^{\text {th }}$ ed. (Meuten, D. J., Ed.) Wiley-Blackwell, USA, pp.1-26.

KELLY, P. A., D. TOOLAN, H. JAHNS (2014): Intestinal adenocarcinoma in a herd of farmed Sika deer (Cervus nippon): a novel syndrome. Vet. Pathol. 52, 193-200.

DOI:10.1177/0300985814521246

MADSEN, T., A. ARNAL, M. VITTECOQ, F. BERNEX, J. ABADIE, S. LABRUT, D. GARCIA, D. FAUGÈRE, K. LEMBERGER, C. BECKMANN, B. ROCHE, F. THOMAS, B. UJVARI (2017): Cancer prevalence and etiology in wild and captive animals. In: Ecology and Evolution of Cancer. $1^{\text {st }}$ ed. (Ujvari, B., B. Roche, F. Thomas, Eds.), Academic Press, pp. 11-46.

MATSON, G. M., L. VAN DAELE, E. GOODWIN, L. AUMILLER, H. REYNOLDS, H. HRISTIENKO (1993): A laboratory manual for cementum age determination of Alaska brown bear PM1 teeth. Alaska Department of Fish and Game and Matson's Laboratory. Milltown, Montana, p. 52. 
MITCHELL, J. W., S. A. THOMOVSKY, A. V. CHEN, A. W. LAYTON, G. HALDORSON, R. L. TUCKER, G. ROBERTS (2015): Medulloblastoma in a grizzly bear (Ursus Arctos Horriblis). J. Zoo. Wildl. Med. 46, 624-628.

DOI: $10.1638 / 2014-0118.1$

MUNDAY, J. S., C. V. LÖHR, M. KIUPEL (2017): Tumors of the alimentary tract. In: Tumors in Domestic Animals, $5^{\text {th }}$ ed. (Meuten, J. D., Ed.) Wiley-Blackwell, USA, pp. 507-601.

MUNK, B. A., J. C. TURNER, M. K. KEEL (2013): Mediastinal teratoma in a free-ranging American black bear (Ursus americanus). J. Zoo. Wildl. Med. 44, 1120-1122.

DOI: 10.1638/2013-0057.1

MURAKAMI, T., Y. KOBAYASHI, S. CHIBA, Y. KURAUCHI, H. SAKAMOTO, M. SASAKI, T. MATSUI (2012): Humeral chondrosarcoma in a Hokkaido brown bear (Ursus arctosyesoensis). J. Vet. Med. Sci. 74, 1195-1197.

PATNAIK, A. K., A. I. HURVITZ, G. F. JOHNSON (1980) Canine intestinal adenocarcinoma and carcinoid. Vet. Pathol. 17, 149-163.

ROSSI, G., F. LAUS, A. PICCININI, R. PICCININI, F. PASQUINELLI, R. GAMBI, E. PAGGI, B. TESEI (2016): Metastasizing ovarian carcinoma in an eurasian brown bear (Ursus arctos arctos): a case report. Slov. Vet. Res. 53, 99-106.

SALAMANCA, J., M. NEVADO, M. A. MARTÍNEZ-GONZÁLEZ, G. PÉREZ-ESPEJO, F. PINEDO (2008): Undifferentiated carcinoma of the jejunum with extensive rhabdoid features. Case report and review of the literature. APMIS 116, 941-946.

DOI: 10.1111/j.1600-0463.2008.00949.x

STORMS, T. N., S. L. BEAZLEY, J. SCHUMACHER, E. C. RAMSAY (2004): Thyroid cystadenoma, colloid goiter, and hypothyroidism in an American black bear (Ursus americanus). J. Zoo. Wildl. Med. 35, 82-87.

DOI: $10.1638 / 03-033$

UZAL, F. A., B. L. PLATTNER, J. M. HOSTETTER (2016): Alimentary system. In: Jubb, Kennedy, Palmer's Pathology of Domestic Animals, Vol. 2., $6^{\text {th }}$ ed., (Maxie, M. G., Ed.), Elsevier, St. Louis, pp. 1-257.

WASHINGTON, M. K. (2008) Colorectal carcinoma: selected issues in pathologic examination and staging and determination of prognostic factors. Arch. Pathol. Lab. Med. 132, 1600-1607.

WILLARD, M. D. (2012): Alimentary neoplasia in geriatric dogs and cats. Vet. Clin. North. Am. Small. Anim. Pract. 42, 693-706.

DOI: $10.1016 /$ j.cvsm.2012.04.006

VASHIST, V. S., S. K. RATTAN, B. B. GUPTA (2013): Papillary cystadenocarcinoma of the mammary gland with metastases to the gastrointestinal tract in a Himalayan brown bear (Ursus arctos). J. Zoo. Wildl. Med. 44, 453-456.

DOI: 10.1638/2011-0093R1.1 


\section{HOHŠTETER, M., I.-C. ŠOŠTARIĆ-ZUCKERMANN， S. RELJIĆ, L. MEDVEN ZAGRADIŠNIK, B. ARTUKOVIĆ, Ž. GRABAREVIĆ, J. KUSAK, Đ. HUBER, A. GUDAN KURILJ: Adenokarcinom crijeva kod smeđeg medvjeda (Ursus arctos) - prikaz slučaja. Vet. arhiv 88, 569-579, 2018. \\ SAŽETAK}

Ovaj članak prikazuje prvi dijagnosticirani slučaj adenokarcinoma crijeva kod 12 godina stare ženke odstrijeljenog slobodnoživućeg smeđeg medvjeda (Ursus arctos), s karakterističnim makroskopskim i histopatološkim svojstvima. Obdukcijom je utrvđena ustrijelna rana (samilosni hitac) na prsnome košu, jaka mršavost s nedostatkom masnoga tkiva i atrofijom mišića. Na jejunumu je ustanovljena infiltrativna masa koja je infiltrirala stijenku crijeva te zahvatila mezenterij, visceralni peritoneum te distalne dijelove rektuma i kolona. Histopatološkom je pretragom utvrđena infiltrativna, neinkapsulirana, umjereno stanična neoplastična masa koja je građena od epitelnih stanica koje formiraju nepravilna gnijezda, papilarne i trakaste strukture te manji broj tubula okruženih jakom dezmoplastičnom reakcijom. Unutar tumora nalazio se manji broj cista ispunjenih sa sluzi. Epitelne neoplastične stanice pokazivale su slabiji stupanj anizocitoze i anizokarioze te nizak mitotski indeks. Histokemijsko Van Giesonovo bojenje pokazalo je jaku pozitivnu reakciju u području dezmoplastične proliferacije. Imunohistokemijska je pretraga pokazala pozitivnu reakciju epitelnih tumorskih stanica na citokeratin, a vezivnotkivnih stanica na vimentin. Utvrđena su histopatološka svojstva karakteristična za adenokarcinom crijeva, mješoviti tubularni i cistični oblik s jakom skiroznom reakcijom.

Ključne riječi: adenokarcinom crijeva; smeđi medvjed (Ursus arctos); patoanatomska pretraga; histopatologija; imunohistokemija 
